3. Отсутствие нормальной связи резко снизило практическую направленность преподавания, что сказалось на качестве усвоения материала.

4. При переходе на дистанционное обучение не была обеспечена (стимулирована) регулярность посещения занятий слушателями и как следствие большинством ( 85 \%) не отработан, заложенный в программу объём часов.

5. При всём этом участники итогового тестировании дистанционно присутствующие на занятиях в большинстве своём показали резкий скачок общеобразовательного уровня знаний по физике (ЕГЭ), в среднем с 45 баллов до 70. Скачок произошёл и в профессиональном уровне знаний с $20 \%$ до $40 \%$ после обучения по предложенной программе обучения на основе ФГОС для бакалавриата нефтегазового направления.

6. Исследование предложенной методики обучения, конкретных вопросов термодинамики и уровня усвоения компетенций при сложившихся условиях оказалось не целесообразным.

$$
* * *
$$

1. Рябов А.А. Итоги работы Ассоциации нефтепереработчиков и нефтехимиков за 2020 г. и план работы на 2021 г. [Электронный ресурс]. - Режим доступа: www.oilref.ru (дата обращения: 09.06.2021 г.)

2. Иванов А. Ю. Наш коллектив способен на многое // РЕГИОН. - 2019. - №4. - С. 4 - 9.

3. Лукойл. Нефтяная компания. [Электронный ресурс]. - Режим доступа: www.lukoil.ru (дата обращения: 10.06.2021 г.)

4. Краткий курс термодинамики / В.Е. Белонучкин. - 2 - е изд., перераб. и доп. - М.: МФТИ, 2010. $164 \mathrm{c.}$

\title{
Карабанова О.P. \\ Феномен готовности к деятельности в профессиональной подготовке военных авиационных специалистов
}

Филиал Военного учебно-научного иеентра Военно-воздушных сил «Военновоздушная академия»

(Россия, Челябинск)

doi: $10.18411 / s r-05-12-2021-31$

\section{Аннотация}

В статье рассматривается феномен готовности к деятельности в профессиональной подготовке авиационных специалистов. Актуальность темы обуславливается тем, что в современных исследованиях установлена тесная взаимосвязь между готовностью к деятельности и результатом профессиональной деятельности на практике. Автор раскрывает определения «готовности к деятельности», объясняет отличие данного феномена от способности к деятельности. Главное внимание обращается на содержание структуры готовности к летной деятельности, в которой выделяется мотивационный, когнитивный, профессиональный и рефлексивный компоненты, дается их краткое описание.

Ключевые слова: готовность, профессиональная подготовка, авиационный специалист.

\section{Abstract}

The article considers the phenomenon of readiness for activity in the professional training of aviation specialists. The relevance of the topic is due to the fact that modern research 
has established a close relationship between readiness for activity and the result of professional activity in practice. The author reveals the definitions of "readiness for activity", explains the difference between this phenomenon and the ability to work. The main attention is paid to the content of the structure of readiness for flight activity, in which motivational, cognitive, professional and reflexive components are highlighted, and their brief description is given.

Keywords: readiness, professional training, aviation specialist.

Проблема готовности к деятельности является одной из насущных в профессиональной подготовке военнослужащих всех видов и родов войск Российской Федерации. Актуальность темы обусловлена тем, что в современных исследованиях установлена тесная взаимосвязь между готовностью к деятельности специалиста и результатом его профессиональной деятельности на практике.

Общие теоретические аспекты готовности человека к деятельности и различные подходы к ее формированию отражены в трудах Б.Г. Ананьева, Н.Д. Виноградова, П.Ф. Каптерева, П.Ф. Лесгафта, А.В. Мудрика, В.А. Сластенина и других.

Часто в науке понятие «профессиональная готовность» отождествляется с понятием «профессиональная подготовка» [1], лексическое значение которой определяет совокупность знаний, умений и навыков.

Также готовность трактуют и как «наличие способностей» (Б.Г. Ананьев, Н.Д. Левитов, С.Л. Рубинштейн); «качество личности» (К.К. Платонов), «психологическую установку» (Д.Н. Узнадзе), «психологическое условие» успешности выполнения деятельности (И. Ладанов); «устойчивую систему профессионально важных качеств личности» (Н.Д. Левитов) и др.

Особо хочется выделить авиационную деятельность, так как она является экстремальной, сопряжена многими неблагоприятными факторами полета и иными условиями, в которых она выполняется.

Готовность человека к деятельности в условиях экстремальных ситуаций рассматривали А.А. Бодров, А.А. Деркач, В.Н. Дружинин, С.В. Кобылянский, Б.В. Кулагин, В.Л. Марищук, В.А. Пономаренко, Б.М. Теплов и др.

В исследованиях подчеркивается, что к авиационному специалисту (летчику, штурману, бортинженеру и др.) предъявляются большие профессиональные требования, начиная от медицинских показателей здоровья до высокого уровня владения профессиональными компетенциями.

Специалист должен быть в постоянном режиме готовности, как долгосрочном, так и краткосрочном; иметь достаточный личностный адаптационный потенциал, обладать необходимыми ресурсами для выполнения деятельности при встрече с любыми непредвиденными обстоятельствами.

Так как мы рассматриваем феномен готовности к деятельности в профессиональной подготовке военных авиационных специалистов, нам близка позиция М.И. Дьяченко, Л.А. Кандыбовича [2, 3], рассматривающих готовность к деятельности как целостное явление, основанное на мотивах и убеждениях, морально-волевых и интеллектуальных качествах личности, знаниях и практических умениях и навыках.

Отметим, что профессиональная подготовка авиационных специалистов имеет ряд особенностей и сопровождается предварительным проведением профессионального отбора в военном комиссариате, затем непосредственно в военном вузе.

Одного желания стать авиатором недостаточно, необходимо иметь достаточно высокие базовые знания по общим дисциплинам школьного курса, высокий уровень физической подготовки, обладать определенным набором профессионально важных качеств.

Аттестационные мероприятия выпускника летного вуза определяют уровень его готовности к профессиональной деятельности, так как наличия одной способности к летной деятельности недостаточно. 
Понятие готовности, по нашему мнению, гораздо шире, так как способность является условием успешного осуществления определенного рода деятельности и развивается из задатков человека в процессе деятельности, а готовность мы рассматриваем как совокупный результат профессиональной подготовки и сформированных компетенций.

Без мотивации к деятельности, убеждений в полезности и ее значимости для общества сама по себе деятельность априори теряет всякий смысл. Вследствие этого важным компонентом готовности к профессиональной деятельности авиационных специалистов мы выделяем мотивационный компонент, включающий внешнюю и внутреннюю мотивацию, ценностные ориентации, военно-профессиональную направленность к военной службе и летному делу.

Сама специфика деятельности авиационного специалиста предполагает владение необходимым набором профессиональных знаний и умений, поэтому вторым компонентом готовности к деятельности мы рассматриваем когнитивный (знаниевый) компонент. Общие и специальные знания служат базой освоения летной профессии, так как специалист должен хорошо разбираться как в авиационной технике и ее управлении, так и в инженерной психологии труда, ряде других наук, непосредственно влияющих на специфику выполнения летной деятельности.

Также важным структурным образованием готовности к деятельности мы считаем профессиональный компонент, включающий наличие развитых профессионально важных качеств авиационного специалиста.

В профессиограмме летчика, штурмана обычно выделяют пять блоков качеств: интеллектуальные, личностные, психофизиологические, физиологические, физические [4].

Без интеллектуальных профессионально важных качеств (развитость ощущений и восприятия, пространственно-образное, логическое мышление, помехоустойчивость мышления, быстрота и точность внимания и др.) не представляется в полной мере овладеть программой обучения и практическими умениями и навыками летной деятельности.

Но в то же время, по мнению В.А. Пономаренко, при ликвидации аварийной или нештатной ситуации, знания, умения, навыки, интеллектуальные способности еще не являются залогом положительного результата; иногда «кроме надежного поведения требуются поступки высокого нравственного содержания» [5]. Поэтому при отборе специалистов летного профиля особое внимание уделяется личностным качествам, включающим адекватную самооценку, целеустремленность, смелость, решительность, чувство долга, патриотизм и др.

При выполнении летной деятельности авиационный специалист испытывает ярко выраженный психофизиологический и психологический стресс (информационный и эмоциональный).

Например, авиационному штурману в большей мере свойственен психологический стресс, так как по своим функциональным обязанностям в жестком лимите времени он перерабатывает большие объемы информации. У него часто возникают информационные перегрузки, при которых «субъект не справляется с решением возникающих проблем, не успевает принимать правильные решения в заданном темпе, в условиях высокой ответственности за последствия принятых решений» [6].

А информационный стресс влияет на уровень физиологического стресса, так как между ними существует корреляционная взаимосвязь.

Исходя из этого положения, в летной работе первостепенными являются и психофизиологические (нервно-эмоциональная устойчивость, устойчивость к монотонии и гипоксии др.); физиологические (вестибулярная устойчивость, 
устойчивость к перегрузке и др.); физические (сила, выносливость, быстрота и др.) профессионально важные качества.

Все блоки профессионально важных качеств значимы для осуществления летной деятельности, имеют интегральный характер, должны комплексно сочетаться и дополнять друг друга.

Также важным структурным элементом готовности к деятельности мы считаем рефлексивный компонент, включающий постоянную обратную связь как стимул к саморазвитию и самосовершенствованию. Авиационный специалист должен иметь развитую способность к анализу, обобщению, конкретизации, а также осмыслению результатов деятельности и продуктивных способов ее осуществления.

Таким образом, феномен готовности к летной профессиональной деятельности представляет собой целенаправленную деятельность профессорско-преподавательского состава, инструкторов, офицеров курсового звена по формированию интегративного качества личности, включающего синтез мотивационного, когнитивного, профессионального и рефлексивного компонентов готовности.

Готовность к деятельности является целью и результатом профессиональной подготовки будущего специалиста, направленной на овладение общими и специальными компетентностями в процессе профессионального становления и развития.

Профессиональная компетентность авиационного специалиста определяется способностью к выполнению необходимых действий, операций и является показателем готовности к осуществлению профессиональной деятельности.

1. Професійна освіта: Словник: Навч. посіб. / Уклад. С.У. Гончаренко та ін.; За ред. Н.Г. Ничкало. К.: Вища школа. 2000. 390 с.

2. Дьяченко М.И., Кандыбович Л.А. Психологические проблемы готовности к деятельности. Минск: Изд-во БГУ. 1976. 176 с.

3. Дьяченко М.И., Кандыбович Л.А., Пономаренко В.А. Готовность к деятельности в напряженных ситуациях: психологический аспект. Минск: Изд-во «Университет». 1985. 206 с.

4. Жданько И.М., Ворона А.А., Запечникова И.В., ,Булавин В.В. Профессионально важные качества как средство повышения профессиональной деятельности летного состава. Военная мысль. 2017. № 9. C.87-93.

5. Пономаренко В.А. Психологические основания личностно-ориентированного кризиса в опасной профессии и пути его преодоления / Вестник МНАПЧАК. 2012. № 3 (41). С. 23.

6. Красильников Г.Т., Крачко Э.А., Мальчинский Ф.В. Разработка методики прогностической оценки устойчивости к профессиональному информационному стрессу летного состава / Российский психологический журнал. 2021. Т. 18. № 1. С. 47-60.

\section{Онишина В.B. \\ Способы преодоления противоречий в работе Школьной службе медиации \\ ГБОУ ВО МО «Академия сочиального управления» (Россия, Москва)}

doi: $10.18411 / s r-05-12-2021-32$

\section{Аннотация}

Школьная служба медиации (ШСМ) предполагает, что помощь в нормализации общения и состояния участников конфликта будет оказана профессионально. Это, в свою очередь означает, что ее будут осуществлять специально обученные люди. Однако не следует забывать, что профессия профессионального переговорщика - это большая редкость. Много времени и сил требуется на подобное обучение, не исключая талант в общении с людьми.

Поискам экспресс-методов обучения медиации посвящена данная статья.

Ключевые слова: медиация, ШСМ (школьная служба медиации), эмоции, конфликтологическая компетентность, психотехники. 